Original Research Paper

\title{
Kegiatan Mengajar Di Desa Gebang Baru Kecamatan Mataram Kelurahan Pagesangan Timur
}

\author{
Yundia Pratiwi Nengsi ${ }^{1^{*}}$, Agil Al Idrus ${ }^{2}$ \\ ${ }^{\text {I} P r o g r a m ~ S t u d i ~ P e n d i d i k a n ~ A n a k ~ U s i a ~ D i n i, ~ F a k u l t a s ~ K e g u r u a n ~ d a n ~ I l m u ~ P e n d i d i k a n, ~ U n i v e r s i t a s ~ M a t a r a m, ~ M a t a r a m, ~}$ \\ Indonesia \\ ${ }^{2}$ Program Studi Pendidikan Biologi, Fakultas Keguruan dan Ilmu Pendidikan, Universitas Mataram, Mataram, Indonesia
}

DOI: https://doi.org/10.29303/jpmpi.v3i2.586

Sitasi:. Nengsi, Y. P,., \& Idrus, A. A. (2020). Kegiatan Mengajar Di Desa Gebang Baru Kecamatan Mataram Kelurahan Pagesangan Timur. Jurnal Pengabdian Magister Pendidikan IPA, 3(2)

\author{
Article history \\ Received: 25 Oktober \\ Revised: 15 Nopember \\ Accepted: 29 Desember \\ *Corresponding Author: \\ Yundia Pratiwi, Program Studi \\ Pendidikan Anak Usia Dini, \\ Fakultas Keguruan dan Ilmu \\ Pendidikan, Universitas \\ Mataram, Mataram, Indonesia \\ Email: yundia@gmail.com
}

\begin{abstract}
Pandemi Covid-19 telah mengganggu proses pembelajaran secara konvensional. Maka diperlukan solusi untuk menjawab permasalahan tersebut. Pembelajaran secara daring adalah salah satu alternatif yang dapat mengatasi masalah tersebut. Dengan adanya kebijakan pemerintah untuk belajar dirumah secara daring, maka peran yang biasanya dilaksanakan oleh satuan pendidikan, sekarang telah berganti fungsi di satuan keluarga, Artinya saat ini rumah menjadi pusat kegiatan bagi semua anggota keluarga terutama orang tua. Namun ada kendala yang dialami orang tua dalam mendampingi anak belajar dirumah meliputi kurangnya pemahaman materi oleh orang tua, kesulitan orang tua dalam menumbuhkan minat belajar anak, tidak memiliki cukup waktu untuk mendampingi anak karena harus bekerja, orang tua tidak sabar dalam mendampingi anak saat belajar dirumah. Dalam pelaksanaan daring ini ternyata orang tua memiliki banyak kendala dalam mendampingi anak belajar dirumah. Penulis melakukan pengabdian pada masyarakat melalui kegiatan Kuliah Kerja Nyata (KKN) Era New Normal ini. Kegiatan yang dilakukan dengan metode Mengajar di Kelurahan Pegesangan Timur telah terlaksana dengan baik tanpa kendala dikarenakan anak-anak sangat antusias dalam membantu terlaksananya program belajar-mengajar ini. Pelaksanaan Kegiatan Mengajar ini di desa Pegesangan Timur dengan tujuan membantu para orang tua siswa juga untuk memotivasi para peserta didik untuk lebih giat belajar dan mengerjakan tugas-tugas dari sekolah dengan semangat dan benar. Motivasi yang kami berikan yaitu dengan metode belajar yang menyenangkan yaitu belajar sambil bermain. Kegiatan ini sangat bermanfaat bagi para peserta didik karena dengan adanya bimbingan belajar ini memberikan motivasi belajar lebih giat serta membantu para peserta didik untuk menyelesaikan tugas-tugas dari sekolah. Selain itu membantu peserta didik untuk mengahadapi ujian semester.
\end{abstract}

Keywords: Kendala orang tua; Masa pandemi; Bimbingan belajar.

\section{Pendahuluan}

Dalam persoalan pandemi Corona atau coronavirus disease 2019 (Covid 19) memberikan banyak pelajaran berharga dalam setiap sendi kehidupan. Sebagian besar karyawan melaksanakan Work FromHome (WFH) dan para siswa juga "memindahkan' kegiatan belajar di rumah, secara online. Ini semua sejalan dengan upaya pemerintah dalam mengurangi dampak penyebaran virus corona. Pemindahan kegiatan belajar dari sekolah 
ke rumah ini, sebagai upaya untuk menjaga jarak sosial, Mau tak mau membuat para orang tua mempunyai peran yang baru, yakni sebagai guru dadakan. Itu artinya, para orang tua lah yang menjadi garda terdepan untuk membimbing proses kegiatan belajar hingga pandemi ini berakhir.

Namun tidak semua orang tua memiliki waktu untuk mengajarkan anaknya dikarenakan mereka harus mencari nafkah dan pengetahuan yang kurang, oleh karena itu banyak sekali para orang tua yang mengeluh menjadi guru dadakan untuk membimbing anak-anaknya belajar di rumahnya masing-masing. Dengan semua persoalan dan keluhan orang tua karena harus menjadi guru dadakan dengan ini kami usulkan program mengajar di desa yaitu "Kegiatan Belajar-Mengajar di Desa Gebang Baru ,Kecamatan Mataram, Kelurahan Pagesangan Timur" ini akan membantu orang tua dalam menyelsaikan tugas daring anaknya dan menambah wawasan serta pemberian motivasi giat belajar untuk anak.Pengadaan kelas belajar ini untuk kalangan peserta didik tingkat sekolah dasar dan taman kanak-kanak. Kami mendapatkan izin dari bapak ketua RT 001 Gebang Baru untuk meminjam rumahnya sebagai tempat kami melaksanakan proses belajarmengajar. Ketua RT sangat mendukung program kami namun dengan catatan kami harus selalu mematuhi pratokol kesehatan dan memberikan contoh yang baik sebagai pendidik. Kepala Pimpinan Keluarahan Pagesangan Timur juga mendukung program kami dan ada beberapa program tambahan usulan dari kepala desa dan kepala lingkungan yaitu ikut serta dalam kegiatan posyiandu, program bagi-bagi masker dan kampong sehat.

Pengadaan Kegiatan Belajar- Mengajar ini dilakukan selain membantu para orang tua siswa juga untuk memotivasi para peserta didik untuk lebih giat belajar dan mengerjakan tugas-tugas dari sekolah dengan semangat dan benar. Motivasi yang kami berikan yaitu dengan metode belajar yang menyenangkan yaitu belajar sambil bermain. Kegiatan ini sangat bermanfaat bagi para peserta didik karena dengan adanya bimbingan belajar ini memberikan motivasi belajar lebih giat serta membantu para peserta didik untuk menyelesaikan tugas-tugas dari sekolah. Selain itu membantu peserta didik untuk mengahadapi ujian semester.

\section{Metode}

Kegiatan ini dilaksanakan 45 hari (Desember-Januari 2020). Pusat segala kegiatan diselenggarakan di Kelurahan Pegesangan Timur. Anak usia 3-6 tahun ini menjadi sasaran utama kegiatan mengajar didesa Metode penelitian yang digunakan adalah metode pendekatan secara langsung dengan cara menganalisa data dari hasil catatan di lapangan atau kegiatan pembelajaran yang telah dilaksanakan serta hasil akhirnya. Penelitian ini dilakukan pada beberapa anak yang terpilih pada kegiatan akhir. Data data yang terkumpul menjadi modal utama untuk menghasilakan tingkatan pemahaman anak, data yang di ambil berdasarkan tingkatan usia dari usia 3-6 Tahun. Total anak anak yang menjadi objek utamanya ada 10 orang anak.

\section{Hasil dan Pembahasan}

Pendidikan Anak Usia Dini sebagai awal jenjang pendidikan tentu sangat memiliki peran sangat penting yang akan menentukan keberhasilan pada jenjang pendidikan selanjutnya. Mendukung pernyataan tersebut adalah Bailey, dalam bukunya berjudul Journal Early Childhood Development, menyebutkan "Early childhood is a critical stage of development that forms the foundation for children's future well-being and learning". Usia dini merupakan periode kritis dalam memberikan pondasi yang akan berpengaruh terhadap pendidikan selanjutnya (Bailey, 2002). Hal tersebut disebabkan pembelajaran baca, tulis dan hitung masih merupakan sesuatu patokan bagi keberhasilan anak di sekolah. Kesulitan yang dihadapi saat belajar baca, tulis, dan hitung menjadikan beban bagi siswa dan menimbulkan tekanan pada siswa.

Kemampuan anak menjawab masih berdasarkan kemampuan menghapal tanpa memahami apa yang dia ajarkan oleh guru. Anak masih kesulitan membedakan dan membandingkan konsep banyak dan sedikit anak berfikir masih mengandalkan indera penglihatan, hampir semua siswa yang mengalami kesulitan belajar baca, tulis dan hitung disebabkan oleh lemahnya konsep perbandingan, akurasi bilangan, identifikasi nomor dan memory kerja yang lemah. (Gersten, Jordan, \& Flojo, 2014). 
Rendahnya kemampuan baca, tulis dan hitung pada siswa di kelurahan pegesangan timur disebabkan salah satunya adalah ketidak mampuan guru menciptakan suasana belajar yang menyenangkan dan interaksi yang aktif antara guru dan siswa. Pembelajaran baca, tulis, dan hitung bukan lagi sebuah mata pelajaran yang seharusnya dapat membantu dalam pemecahan permasalahaan pada mata pelajaran lain, justru malah menjadi penghambat motivasi siswa untuk belajar.

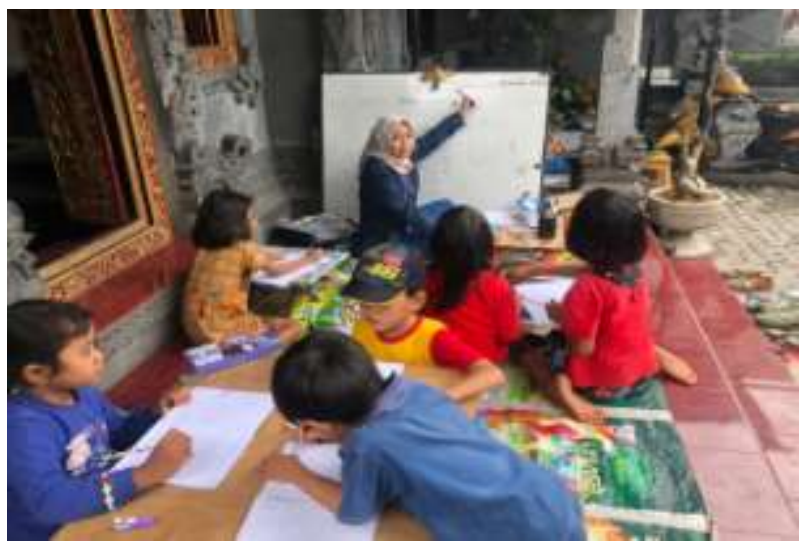

Gambar 1. Proses Kegiatan Belajar-Mengajar

Kegiatan mengajar didesa CALISTUNG adalah pembelajaran baca, tulis dan hitung yang menyenangkan, dilakukan kepada anak-anak yang berada di kelurahan pegesangan Timur, pembelajaran ini di pembelajaran ini pada umumnya di harapkan dapat memberi pengalaman yang berbeda untuk anak anak dalam belajar CALISTUNG (Baca, Tulis dan Hitung), khususnya pada pengenal huruf dan angka untuk anak anak usia 3-6 Tahun didesa Pegesangan Timur. Dari beberapa pengalaman yang di temukan di lapangan, masih banyak anak anak yang mengalami kesulitan dalam memahami baca, tulis dan hitung, hal ini di karenakan masih kurangnya pemahaman terkait prinsip atau dasar dasar mambaca, menulis dan berhitung yang menjadi modal utama anak anak untuk memahami pembelajaran pada tingkatan selanjutnya.

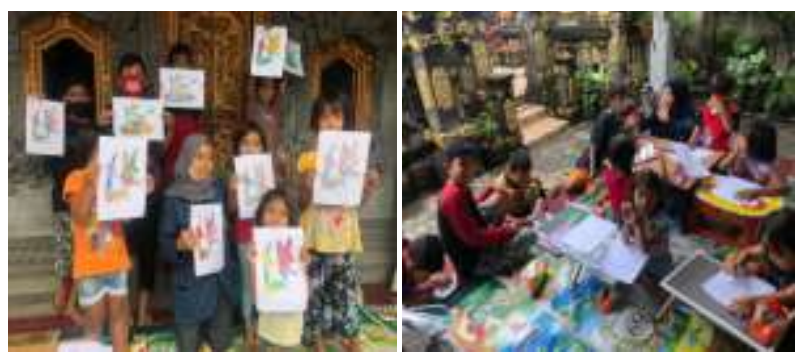

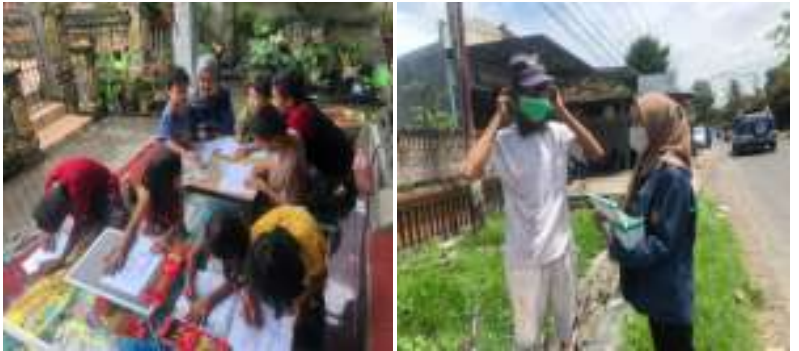

Gambar 2. Kegiatan CALISTUNG dan kemasyarakatan

Membaca, menulis, dan berhitung sebagai pelajaran dasar upaya untuk membekali anak. Calistung adalah hal yang mendasar yang perlu dikenalkan kepada anak sejak dini dan menjadi modal utama anak dalam proses pembelajaran di jenjang pendidikan yang lebih tinggi. Baca tulis adalah perkembangan dari keterampilan membaca dan menulis maupun tindakantindakan kreatif serta analitis dalam memproduksi dan memahami teks bacaan atau buku cerita. Membaca dan menulis dan berhitung anak akan mampu menyerap dan menyampaikan segala informasi yang diterimanya dan dengan berhitung anak lebih mampu mengembangkan aspek kognitif anak, terutama memaksimalkan fungsi belahan otak kirinya. Kemampuan membaca sebagai pintu gerbang kognitif yang memegang peranan penting dalam keseluruhan kehidupan manusia terutama membuat kontak dan berkomunikasi dengan pikiran dan imajinasi, dan sebagai dasar pendidikan untuk menulis.

\section{Kesimpulan}

Dari awal pelaksanaan Program Kegiatan Belajar Mengajar di Desa Gebang Baru Kelurahan Pagesangan Timur, Kecamatan Mataram anak-anak sangat antusias dalam mengikuti KBM dan bekerjasama dengan baik. Ada 10 anak yang mengikuti bimbingan belajar. Hasil yang diharapkan mahasiswa KKN adalah sebagai berikut, Siswa dapat memahami tentang dirinya sendiri, khususnya pada kemampuan belajarnya, Siswa dapat memperbaiki cara belajarnya ke arah yang lebih efektif dan efisien, Siswa dapat mengatasi berbagai macam kesulitan belajarnya, Siswa dapat mengembangkan sikap, kebiasaan, dan tingkah laku yang lebih baik, khususnya yang berkaitan tentang belajarnya. dapat trampil dalam melaksanakan kegiatan belajar dan dapat mencapai prestasi belajar yang optimal. Mengenal dan memahami potensi atau peluang yang ada di 
lingkungannya, kemampuannya untuk kepentingan dirinya, kepentingan lembaga tempat bekerja dan masyarakat. Menyesuaikan diri dengan keadaan dan tuntutan dari lingkungannya. Mengembangkan segala potensi dan kekuatan yang dimilikinya secara optimal

\section{Ucapan Terima Kasih}

Terima kasih kepada Universitas Mataram yang telah mendukung secara moral maupun material, dan pihak-pihak terkait yang senantiasa selalu memberikan dukungan dalam terlaksan. Serta terima kasih kepada anak-anak yang mengikuti kegitan mengajar didesa Pegesangan lingkungan gebang baru

\section{Daftar Pustaka}

Departemen Pendidikan Nasional. 2010. Peraturan

Pemerintah Republik Indonesia Nomor 66 Tahun 2010, Tentang Perubahan Atas Peraturan Pemerintah Nomor 17 Tahun 2010 Tentang Pengelolaandan Penyelenggaraan Pendidikan. Jakarta: Depdiknas.

Dewintaprasti. 2012. Manfaat Dari Bimbel. Diunduh dari http://dewintaprasti. wordpress.com Tanggal 6 Desember 2020.

Idris, Zahara dan Lisman Jamal. 1992. Pengantar Pendidikan. Jakarta: PT Gramedi Widiasarana Indonesia

Sukmadinata, Nana Syaodih. 2005. Landasan Psikologi Proses Pendidikan. Bandung: PT Remaja Rosdakarya.

Winkel. 1996. Pengertian Prestasi Belajar Menurut Para Ahli. Diunduh dari http://www.anneahira.com Tanggal 6 Desember 2020. 